went to the university initially to study theology (later he switched to philology), knew the Bible inside-out and by heart, and came from a family of pious Lutheran theologians. It was his later life experiences that brought him into a profound spiritual crisis that ultimately shattered his faith once and for all. But he went beyond mere disbelief to become an aggressively and fiercely anti-religious atheist (even calling himself the "Antichrist" and the "first immoralist"). Rarely noticed however, is that this antagonism was born precisely because of his attachment to religion, or to use Hamlet's line, he "doth protest too much". Nietzsche's agony was thus a spiritual crisis within a religious context against a socio-cultural backdrop hostile to it, different from Foucault's largely philosophical dilemma. Like many Muslims today, Nietzsche sensed a serious lack of synchrony between the Christian values that he espoused and the prevailing secular humanistic ideals of his contemporaries, but instead of resisting the latter, he succumbed to it. And here there may be signs of hope, for the conditions of late modernity could have easily produced Nietzsches out of Muslims, but they have not.

Despite going against radicalism, Murad's prescription itself is radical but profound: the defeat of the current global system and its replacement with the "ethical brilliance of monotheisms". And this partly means of course, the inner life of spirituality, the heart's idyllic sanctuary wherein the presence of the Divine is experienced most. Self-judgment, the "greatest and most irreplaceable gift of the Abrahamic religions" should be cultivated more. At the same time, the war on such ideologies cannot be severed from the "humanly consensual war on environmental loss, on unfair trade, on identity feminism, and on genetic manipulation". If we understand this reasoning correctly, the author calls for a theological orientation that addresses such contemporary crises while remaining theologically and spiritually true to its roots. Perhaps it is by this means that the asymmetry between religion and ordinary life can finally be put to an end.

\title{
Wang Yong Bao (Ahmed Musa). Diplomacy: Theory and Practice in Islam
} (Kuala Lumpur: International Islamic University Malaysia Press, 2009). xxiv + 243pp. ISBN 978-983-3855-97-1. MYR 38.00.

\section{Karim D. Crow International Institute of Advanced Islamic Studies (IAIS) Malaysia}

The topic of diplomatic practice and international relations in Islam has attracted a growing interest in modern Muslim thought, revisiting the rich legacy of juristic and historical treatments addressing interconnected issues relating to diplomacy. This study by a Chinese scholar with solid training in Arabic and Islamic thought, who took his BA in Libya and his MA and PhD degrees in Malaysia, is a welcome 
and worthy contribution to this discussion. Dr. Musa is currently Associate Professor at the School of Oriental Studies, Xi'an International Studies University (China). We first summarise the contents of his work, and then offer brief reflections on his handling and approach to the topic.

After a foreword by former Malaysian Prime Minister Tun Mahathir Mohamad and the preliminary matters, six chapters treat the main areas of his research, which may be divided into two parts. The first three chapters (pp. 1-84) provide general overviews on the Islamic legal tradition concerning 1) "Characteristics of Diplomacy," 2) "Diplomats and Diplomatic Mechanisms," and 3) "Principles and Types of Diplomacy." Chapters 4-6 (pp. 85-199) discuss in greater detail and depth three important aspects of diplomatic practice in Muslim experience: 4) "Diplomatic Privileges and Immunities," 5) "Status of Diplomats and their Functions during War," and 6) "International Transactions."

1) "Characteristics of Diplomacy" (pp. 1-40). Affirming that Islam "requires the Muslims always to conduct peaceful relations with the non-believers in this world" and that "Muslims have demonstrated the universal characteristics of Islam throughout history" (p. 1), the author emphasises fundamental principles characterising Islam's approach to non-Muslims. These are freedom of faith, justice and inherent human dignity, equality, tolerance (tasāmuh), and peaceful relations with others. Under 'peaceful relations' the vexed question of the abrogation of qur'ānic verses with an apparent contradiction between the Prophet's Meccan peaceful persuasion and the Medinan sword verses is dealt with (pp. 16-25). Professor Musa rejects any contradiction between these two classes of verses, harmonising the earlier peaceful $j i h \bar{a} d$ of persuasion with the later combative $j i h \bar{a} d$ of the sword purely for defensive intent: "the allegation that Jihäd is being used by Muslims to compel others to embrace Islam is mere lie and willful vilification on Islam" (p. 22). However, he also points to juridical usage and conceptions, which indeed tended to privilege military conquest. Then the meaning of diplomacy in Western conception, and the Islamic notion, is compared. Professor Musa offers us his own definition of diplomacy in Islamic terms (p. 29):

The art of conducting external relations and preserving the objectives of the Islamic State with other states or international organizations by applying wisdom and intelligence in order to reconcile the conflicts in the best manner.

His definition begs the question of what constitutes the 'Islamic State' in the twentyfirst century, whose diplomats should "conduct external relations for the path of Allah so that the people of the host states may embrace Islam" (p. 30). This tendency towards the a-historical idealising of 'Islam' and Muslim teachings is evident throughout his work - indeed it forms a typically naïve feature of contemporary Muslim intellectual projects that Muslims remain unaware of. 
2) "Diplomats and Diplomatic Mechanisms." This brief chapter treats the main methods of diplomatic exchange: selection and qualities of envoys and messengers, their intelligence and linguistic competence, dispatching letters, presenting gifts, use of ciphers, and an office for external relations. Musa cites examples from the career of the Prophet Muhammad including his famous dispatching of envoys bearing letters to the ruling powers of his day in year $7 \mathrm{AH}$, and displays skillful use of early Islamic sources.

3) "Principles and Types of Diplomacy in Islam." Musa reviews general features of Islamic diplomatic practice, citing qur'ānic verses and Prophetic Sunnah in support. These cover mutual agreement, respect for the customs and laws of the receiving State, reciprocity in dealing with other entities (subject of specific restrictions or limits), non-interference in domestic affairs of the receiving State, and free communication regarding the official objectives. He describes the specific principles of diplomacy to be good intent and non-betrayal of trust, justice, fulfilling agreements agreed between two sides, and prohibition of espionage. Then Musa treats a variety of types of diplomatic practice: temporary diplomacy and long-term diplomacy, diplomacy employing both professional and non-professionals as well as by ordinary citizens, secret diplomacy, and public diplomacy. Here he refers to a number of historical events from classical Muslim history exemplifying these various types. Musa affirms that "the Islamic State has never closed its doors to non-Islamic states and their subjects, but has provided a free and secure zone for their diplomats to fulfill their missions," and that "Islamic diplomacy has strictly and sincerely abided by general Islamic principles in their diplomatic affairs with other states ..." (p. 81).

4) "Diplomatic Privileges and Immunities" (pp. 85-134). In the longest chapter of the book, Musa demonstrates his competence in contemporary Western studies, and in the wealth of Islamic juridical texts providing details on this key aspect of diplomatic practice at the level of official relations between states. The chief topics discussed include personal privileges; freedom of travel in the host state; judicial immunity ( $a m \bar{a} n)$ for foreign diplomats exempted from shar $\bar{l}^{c} a h$ judgments with close review of four major conflicting opinions entertained among jurists; the exemption of diplomatic missions from taxation and regulations concerning diplomatic premises; and diplomatic asylum. The last section in this chapter (pp. 109-124) provides a good overview of the issue of terminating diplomatic privileges and immunities as documented in the $\operatorname{sharl}^{2} a h$. Musa does a fine job of arranging and presenting these complex details in a clear and graspable manner and his command of the juridical sources is impressive.

5) "Status of Diplomats - their Functions during War." This brief chapter summarises general Islamic principles about the conduct of diplomacy during wartime, including such topics as prisoners of war, espionage, and revoking the pact of security (amān) granted previously. Perhaps this chapter focuses too closely upon 
these issues, for Musa does not engage with wider and more fundamental questions about war-making and peace-making flowing from conflict or hostilities. Conflict resolution, cease-fires and truces, and cessation of bloodshed could have been accorded more rigorous examination than is done here. Creative attention might also have been paid to the aftermath of war and peace-building in war-torn societies given that so many Muslim societies today confront these painful questions. Here, the focus is strictly on the diplomatic dimension.

6) "International Transactions - Conducting Negotiations in Islam" (pp. 155-199). This lengthy chapter treats the role of diplomacy for negotiation and concluding treaties and agreements (mu'ähadah, mìthāq) following the writer's combined historical and juridical approach. Musa offers us a well organised digest of this key topic, especially his review of the types of treaty struck between states with their conditions (pp. 176-192). While avoiding drowning the reader in legal details (for which consult the fundamental study by Wahbah al-Zuhaylī, Äthār al-harb fí 'l-fiqh al-islāmī, Damascus, 1965), Musa at least introduces the reader to some complexities and indicates the richness of Islamic practice and theory. For a work of this scope, more than this is probably not required.

This final view is capped by the "Conclusion" (pp. 201-218) where the results of his study are recapitulated and summarised. Certain of these may strike one as 'preaching' to the leaders and diplomats of Muslim states, which is certainly understandable given the obvious un-Islamic conduct of certain polities. However, his points are well-taken and bear reinforcement: the universality of Islamic principles entails stressing freedom of faith, justice and inherent human dignity, equality, tolerance (tasāmuh), and peaceful relations with others. He underlines that "the Islamic understanding of diplomacy is different from the Western one." Finally Musa provides seven brief recommendations for the contemporary practice of diplomacy by Islamic nations. Chief among these is to teach "Diplomacy: theory and practice in Islam" as a subject in ministries of foreign affairs and at universities and specialised colleges devoted to international affairs, in order to equip diplomats and politicians to better understand the true Islamic dimension in international relations. $\mathrm{He}$ also calls for more intense scholarly discussion on Islamic diplomacy to better educate Muslims on its true features and promote more authentic adherence to justice and equity, as well as pursue further comparative studies on Islamic and Western diplomatic in the modern period.

Professor Musa/Wang sought in this book "to formulate an Islamic theory and practice of diplomacy" (p. 217). He has certainly taken an important step toward realising his goal, but as he himself recognises, - more has to be accomplished. In his Introduction the author stated (p. xvii): “[...] when we talk about Islam, we cannot separate it from the state, because once the Islamic State is established, all of its affairs should be conducted according to Islam and practiced fully in the way which 
Islam directs." He then laments the adoption by leaders of Muslim nations in the post-colonial era of "the Western secular political systems" to handle their affairs, reflecting "their ignorance of Islamic values, merits, and especially vision..." The reality he evokes is indeed a sore wound that has multiplied the sufferings of Muslim countries in recent decades. However, the perception that this is a uniquely modern situation, and 'Islam' was more fully implemented and practised in the past, needs to be re-examined. The simplistic glorification of an idealised past has clouded much of contemporary Muslim thinking and various Islamic political projects for an 'Islamic State', so it is vital that responsible researchers not perpetuate such cherished soothing myths. A self-critical and honest appraisal of the strengths and weaknesses which our past imposes is necessary for Muslims to move forward and construct their own authentic mode of modernity. Diplomatic practices form one important component of that enterprise.

\section{Saim Kayadibi (ed.), Ottoman Connections to the Malay World: Islam,} Law and Society (Kuala Lumpur: The Other Press, 2011) 267 pp. ISBN 978983954-177-9. MYR 39.00

\section{Eric Winkel International Institute of Advanced Islamic Studies (IAIS) Malaysia}

This book is a carefully researched work that may serve as an important resource for the study of Ottoman and other Muslim connections and networks to the Malay Archipelago. The spread of Islam in the region through trade is well documented here. The authors of the seven articles contained in this volume have used original sources - many of them very little known or used in contemporary scholarship. The authors are strongly supported by their sources to contribute to a re-writing of the history of this region.

The chapter "The Religious-Intellectual Network: The Arrival of Islam in the Archipelago" by Nurulwahidah binti Fauzi, Ali Mohammad, and Saim Kayadibi corrects common misperceptions about Islam, the Arabian lands, and Southeast Asia and shows them to be intimately linked. In the early period, it was natural for the Arabs to extend their trading relations to the Malay Archipelago. The early ArabPersian records trace Arab connections with Malaya and Indonesia back to the midninth century. Islam spread through trade and education (e.g., establishing pesantrens) in this region. This chapter also examines the important network of Hadrami Arabs and Johor. By the late nineteenth century, the Arab community in Glam Village (Singapore) was described by Dutch scholar L. W. C. Van den Berg in 1886 as "the most flourishing, though not the largest, Arab colony in the Indian Archipelago." The 